Article

\title{
Nitrogen-doped ordered mesoporous carbon: Effect of carbon precursor on oxygen reduction reactions
}

\author{
Xiao-hua Li a, Kai Wan a, Quan-bing Liu a, Jin-hua Piao b, Yu-ying Zheng c , Zhen-xing Liang a,* \\ a Key Laboratory on Fuel Cell Technology of Guangdong Province, School of Chemistry and Chemical Engineering, South China University of Technology, \\ Guangzhou 510641, Guangdong, China \\ b School of Food Science and Engineering, South China University of Technology, Guangzhou 510641, Guangdong, China \\ 'School of Chemical Engineering and Light Industry, Guangdong University of Technology, Guangzhou 510006, Guangdong, China
}

\section{A R T I C L E I N F O}

\section{Article history:}

Received 31 May 2016

Accepted 29 June 2016

Published 5 September 2016

\section{Keywords:}

Electrocatalysis

Fuel cell

Nitrogen-doped ordered mesoporous

carbon

Oxygen reduction reaction

Precursor

\begin{abstract}
A B S T R A C T
Aniline, pyrrole and phenanthroline, which have different nitrogen compositions, are used as carbon precursors to synthesize nitrogen-doped ordered mesoporous carbons (NOMCs) by the nanocasting method. The effect of the precursor on the resultant NOMC is extensively investigated by nitrogen adsorption-desorption measurements, scanning electron microscopy, X-ray photoelectron spectroscopy (XPS), cyclic voltammetry and rotating ring-disk electrode measurements. Salient findings are as follows. First, the precursor has a significant influence on the specific surface area and textural properties. The NOMC materials derived from pyrrole (C-PY-900: $765 \mathrm{~m}^{2} / \mathrm{g}$ ) and phenanthroline (C-Phen-900: $746 \mathrm{~m}^{2} / \mathrm{g}$ ) exhibit higher specific surface areas than the aniline analog (C-PA-900: $569 \mathrm{~m}^{2} / \mathrm{g}$ ). Second, the XPS results indicate that the total nitrogen content (ca. 3.1-3.3 at\%) is similar for the three carbon sources, except for a slight difference in the nitrogen configuration. Furthermore, the content of the nitrogen-activated carbon atoms is found to closely depend on the precursor, which is the highest for the phenanthroline-derived carbon. Third, the electrochemical results reveal that the electrocatalytic activity follows in the order C-PA-900 < C-PY-900 < C-Phen-900, confirming that the nitrogen-activated carbon atoms are the active sites for the oxygen reduction reaction (ORR). In summary, the precursor has considerable influence on the composition and textural properties of the NOMC materials, of which the ORR electrocatalytic activity can be enhanced through optimization of the NOMCs.
\end{abstract}

(C) 2016, Dalian Institute of Chemical Physics, Chinese Academy of Sciences. Published by Elsevier B.V. All rights reserved.

\section{Introduction}

The polymer electrolyte membrane fuel cell (PEMFC) has been widely regarded as the next-generation energy technology because of advantages related to zero emission, high efficiency and energy density [1-3]. Currently, the commercialization of PEMFCs is economically unviable because of high cata- lyst costs resulting from the requirement of large quantities of the noble metal Pt [4]. It is, therefore, highly desirable to develop non-precious metal catalysts [5], or alternatively, metal-free carbonaceous catalysts [6-9].

Among the alternatives, the nanostructured nitrogen-doped carbon is of particular interest, which shows promise in energy storage and conversion applications $[10,11]$. However, chal-

\footnotetext{
* Corresponding author. Tel: +86-20-87113584; E-mail: zliang@scut.edu.cn

This work was supported by the National Natural Science Foundation of China (21476087, 21576101), the Innovation Project of Guangdong Department of Education (2014KTSCX016), the Science \& Technology Research Project of Guangdong Province (2013B010405005, 2014A010105041), and the Fundamental Research Funds for the Central Universities.

DOI: 10.1016/S1872-2067(16)62498-1 | http://www.sciencedirect.com/science/journal/18722067 | Chin. J. Catal., Vol. 37, No. 9, September 2016
} 
lenges remain to further increase the activity and stability of carbon catalysts. Enormous efforts have been devoted to optimizing a controllable synthesis. Among the conditions, the precursor is believed to play a key role in determining the composition, structure and resulting final properties of the final carbon catalyst. For example, diaminobenzene [12], aminoglucose [13], ethylenediamine [14], polyaniline [15], and phenanthroline [16] have been explored, which are reported to yield different activities.

It should be pointed out that the electrocatalytic activity cannot easily be directly compared as both the synthesis and evaluation were conducted by different research groups under differing conditions. As such, the precursor effect needs to be explicitly investigated as to how it influences composition, structure and electrocatalysis for oxygen reduction reactions (ORRs). In our previous work, nitrogen-doped ordered mesoporous carbons (NOMCs) were synthesized by a modified nanocasting method, which exhibited high specific surface areas, uniform pore structures and excellent electrocatalytic activity [17]. In this work, individual NOMCs are synthesized using three precursors, aniline, pyrrole, and phenanthroline, each having varying nitrogen compositional structures. The effect of the precursor on the resultant NOMC is extensively investigated by nitrogen adsorption-desorption measurements, scanning electron microscopy (SEM), X-ray photoelectron spectroscopy (XPS), cyclic voltammetry (CV), and rotating-ring-disk electrode (RRDE) methods.

\section{Experimental}

\subsection{Synthesis of the NOMC catalysts}

NOMCs were synthesized via a nanocasting method using SBA-15 as the template [17-19]. First, $3.2 \mathrm{~g} \mathrm{SBA-15}$ was dispersed in an ethanol solution $(20.0 \mathrm{~mL}$ ethanol $+20.0 \mathrm{~mL}$ deionized water). Second, $4.0 \mathrm{~g}$ phenanthroline was dissolved in $10 \mathrm{~mL}$ ethanol and mixed with a $\mathrm{FeCl}_{2}$ aqueous solution. The molar ratio of iron to phenanthroline was 1:3 to ensure complete coordination. Thereafter, the above two solutions were mixed and sonicated for $6 \mathrm{~h}$. The resulting powder was filtered, washed and subjected to pyrolysis at high temperatures (700, $800,900,1000^{\circ} \mathrm{C}$ ) for $3 \mathrm{~h}$ under an $\mathrm{Ar}$ atmosphere. Finally, the NOMC catalysts were obtained by removing the silica template and $\mathrm{Fe}$ species. The template was removed by refluxing the powders in $10 \mathrm{~mol} / \mathrm{L} \mathrm{NaOH}$ at $120{ }^{\circ} \mathrm{C}$ for $24 \mathrm{~h}$, and the iron species was leached by boiling the powders in $0.10 \mathrm{~mol} / \mathrm{L}$ $\mathrm{HClO}_{4}$ at $80{ }^{\circ} \mathrm{C}$ for $24 \mathrm{~h}$. The samples were referred to as C-Phen- $x$. Here, $x$ refers to the pyrolysis temperature, viz. 700, 800,900 , and $1000{ }^{\circ} \mathrm{C}$.

The pyrrole- and aniline-derived carbon catalysts, C-PY-900 and C-PA-900, were synthesized as described in our previous work $[20,21]$. Pyrolysis was conducted at $900{ }^{\circ} \mathrm{C}$ for $3 \mathrm{~h}$ under an Ar atmosphere.

\subsection{Physiochemical characterizations}

X-ray diffraction (XRD) measurements were performed us- ing a Bruker D8 ADVANCE diffractometer employing a $\mathrm{Cu} K_{\alpha}$ radiation source operating at $40 \mathrm{kV}$ at a scan rate of $10^{\circ} / \mathrm{min}$. XPS (Physical Electronics PHI 5600) measurements were carried out with a multi-technique system using an Al monochromatic X-ray source at a power of $350 \mathrm{~W}$. Transmission electron microscopy (TEM) images were taken on a FEI Tecnai G2 F20 S-TWIN operating at $200 \mathrm{kV}$. Nitrogen adsorption-desorption isotherms were measured at $-196{ }^{\circ} \mathrm{C}$ using a Micromeritics TriStar II 3020 analyzer. Total surface area was determined by the Brunauer-Emmett-Teller (BET) method, the microporous (MP) surface area was obtained via the $t$-plot method, and the pore size distribution was analyzed using the Barrett-JoynerHalenda (BJH) method.

\subsection{Electrochemical test}

The electrochemical behavior of the catalysts was characterized by CV and linear sweeping voltammetry (LSV) methods using a three-electrode cell with a Zennium electrochemical work station (Zahner) at room temperature $\left(25^{\circ} \mathrm{C}\right)$. A gold wire and a double junction $\mathrm{Ag} / \mathrm{AgCl}$ reference electrode (PINE) were used as the counter and reference electrodes, respectively. The working electrode was a RRDE (glassy carbon disk: 5.0 $\mathrm{mm}$ in diameter, platinum ring: $6.5 \mathrm{~mm}$ inner diameter and 7.5 $\mathrm{mm}$ outer diameter). The thin-film electrode on the disk was prepared as follows: $10 \mathrm{mg}$ of the catalyst was dispersed in 1.0 mL Nafion/ethanol ( $0.84 \mathrm{wt} \%$ Nafion) by sonication for $2 \mathrm{~h}$. Thereafter, $10 \mu \mathrm{L}$ of the dispersion was transferred by pipette onto the glassy carbon disk, yielding a catalyst loading of 0.50 $\mathrm{mg} / \mathrm{cm}^{2}$. For comparison, we also measured the ORR electrocatalytic activity of a commercial $40 \mathrm{wt} \% \mathrm{Pt} / \mathrm{C}$ catalyst (HiSPEC4000, Johnson Matthey) having a metal loading of 20 $\mu \mathrm{g} / \mathrm{cm}^{2}$.

A $\mathrm{KOH}$ electrolyte solution $(0.10 \mathrm{~mol} / \mathrm{L})$ was first bubbled with $\mathrm{Ar}$ for $1 \mathrm{~h}$. Thereafter, the CV test was conducted at 20 $\mathrm{mV} / \mathrm{s}$ across the potential range of $0-1.23 \mathrm{~V}$ (vs. reversible hydrogen electrode, RHE) for 20 cycles. If unspecified, the LSV curve was collected by scanning the disk potential from 1.2-0 V at $5 \mathrm{mV} / \mathrm{s}$ in the oxygen-saturated electrolyte solution under $1600 \mathrm{r} / \mathrm{min}$, from which the ORR polarization curve was extracted by subtracting the capacitive current. During the collection, the potential of the ring was set as $0.5 \mathrm{~V}$ (vs. RHE) to determine the yield of hydrogen peroxide, respectively.

The electron transfer number $(n)$ and hydrogen peroxide yield in the ORR was calculated from the following equations:

$$
\begin{aligned}
n & =\frac{4\left|i_{\mathrm{d}}\right|}{\left|i_{\mathrm{d}}\right|+i_{\mathrm{r}} / N} \\
\mathrm{H}_{2} \mathrm{O}_{2} & =\frac{2 i_{\mathrm{r}} / N}{\left|i_{\mathrm{d}}\right|+i_{\mathrm{r}} / N} \times 100 \%
\end{aligned}
$$

where $i_{\mathrm{d}}$ is the disk current, $i_{\mathrm{r}}$ is the ring current, and $N$ is the collection efficiency $(=20.50 \%)$.

\section{Results and discussion}

Fig. 1 presents the nitrogen adsorption-desorption isotherms of the synthesized C-PA-900, C-PY-900, and 


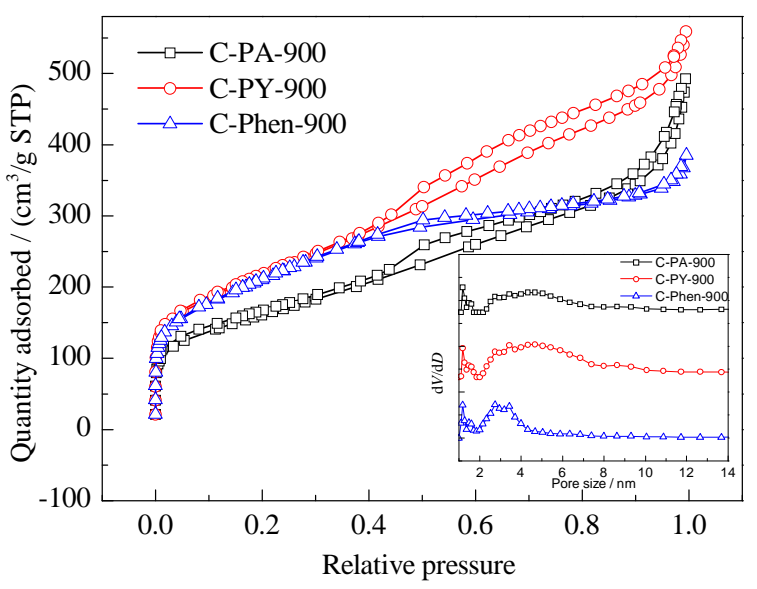

Fig. 1. Nitrogen adsorption-desorption isotherms and pore size distribution (inset) of the synthesized NOMC materials.

C-Phen-900. It can be observed that all the curves display a type-IV isotherm, indicating their mesoporous structure. The textural parameters are listed in Table 1. For C-PA-900, C-PY-900, and C-Phen-900, the total BET specific surface areas are 569,765 and $746 \mathrm{~m}^{2} / \mathrm{g}$, respectively; in comparison, the MP specific surface areas are 41,49 and $7 \mathrm{~m}^{2} / \mathrm{g}$, respectively. Thus, it is inferred that the specific surface area is attributed to the mesopores having diameters in the range of 3.7-5.9 nm, which ensures accessibility to the electroactive species in liquid electrolytes. In comparing the three materials, even though the specific surface areas are sufficiently high to achieve acceptable electrocatalytic activity, as seen below, the textural property data strongly indicate that the precursor influences the pore structure-thought to originate from the difference in the thermodecomposition of the three macromolecules.

Fig. 2 shows the TEM micrographs of the three NOMC materials. All samples exhibit highly ordered mesoporous channels-the electron density of which is the inverse replica of the SBA-15 template. The pores run parallel and are uniform in diameter (3-6 nm). The results are consistent with the above physical adsorption analysis.

The XRD patterns are shown in Fig. 3. Two wide diffraction peaks are observed centered at $2 \theta=25.2^{\circ}$ and $43.7^{\circ}$, which are indexed to the (002) and (100) planes, respectively [22]. The results indicate that all three NOMCs are amorphous in nature and the precursor does not yield noticeable effects on the crystalline structure.

XPS analysis allowed elemental information on the NOMC surface to be obtained. Quantitative results are listed in Table 2. The nitrogen content is 3.13 at $\%, 3.32$ at $\%$ and 3.33 at $\%$ for C-PA-900, C-PY-900, and C-Phen-900, respectively, suggesting that the precursor has a slight influence on the doped nitrogen

Table 1

Textural properties of the synthesized NOMC materials.

\begin{tabular}{lcccc}
\hline Sample & $A_{\text {BEт }} /\left(\mathrm{m}^{2} / \mathrm{g}\right)$ & $A_{\mathrm{MP}} /\left(\mathrm{m}^{2} / \mathrm{g}\right)$ & $D / \mathrm{nm}$ & $V /\left(\mathrm{cm}^{3} / \mathrm{g}\right)$ \\
\hline C-PA-900 & 569 & 41 & 5.9 & 0.80 \\
C-PY-900 & 765 & 49 & 5.0 & 0.92 \\
C-Phen-900 & 746 & 7 & 3.7 & 0.64 \\
\hline
\end{tabular}

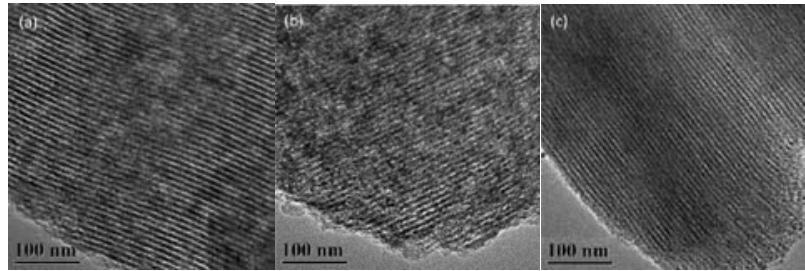

Fig. 2. TEM images of the synthesized NOMC materials. (a) C-PA-900; (b) C-PY-900; (c) C-Phen-900.

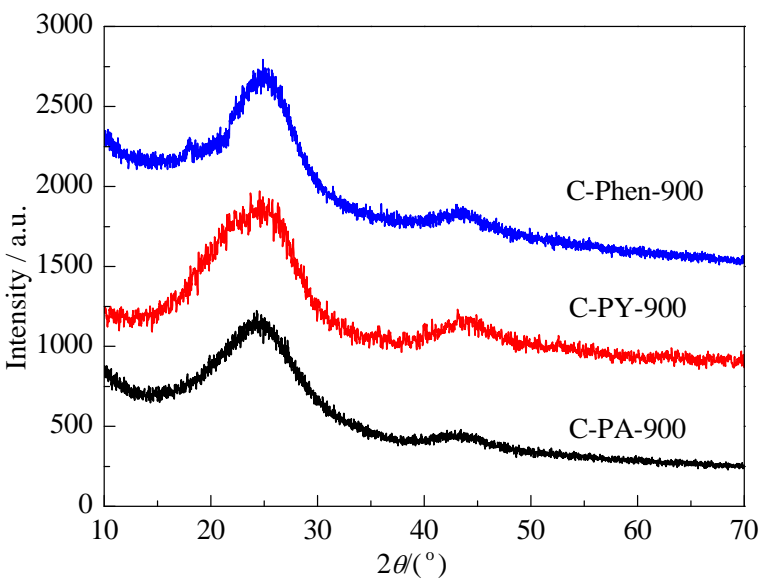

Fig. 3. XRD patterns of the synthesized NOMC materials.

content. In comparison, the pyrolysis temperature shows a significant influence in determining the surface composition (Table 3). The nitrogen content shows a dramatic decrease from 7.44 at $\%$ to 2.12 at $\%$ as a function of increasing pyrolysis temperature from 700 to $1000{ }^{\circ} \mathrm{C}$. Conversely, in addition to nitrogen content, it is acknowledged that the coordination of the nitrogen dopant is equally important for electrocatalysis [23].

Accordingly, structural information on the nitrogen dopant is resolved by fitting the $\mathrm{N} 1 s$ spectra into three peaks residing at $398.4 \pm 0.2,401.0 \pm 0.1$, and $401.5-404 \mathrm{eV}$, which correspond to pyridinic-, graphitic- and oxide-nitrogen (Fig. 4) $[20,24,25]$, respectively. First, the shapes of the curve are simi-

Table 2

Elemental composition of the synthesized NOMC materials.

\begin{tabular}{lcccc}
\hline \multirow{2}{*}{ Sample } & \multicolumn{3}{c}{ Element composition (at\%) } & \multirow{2}{*}{ N:C } \\
\cline { 2 - 4 } & $\mathrm{C}$ & $\mathrm{N}$ & $\mathrm{O}$ & \\
\hline C-PA-900 & 92.03 & 3.13 & 4.40 & 0.034 \\
C-PY-900 & 92.47 & 3.32 & 3.72 & 0.036 \\
C-Phen-1000 & 89.65 & 3.33 & 6.50 & 0.037 \\
\hline
\end{tabular}

Table 3

Elemental composition of C-Phen synthesized as a function of pyrolysis temperature.

\begin{tabular}{lccrc}
\hline \multirow{2}{*}{ Temperature $\left({ }^{\circ} \mathrm{C}\right)$} & \multicolumn{3}{c}{ Element composition (at\%) } & \multirow{2}{*}{$\mathrm{N}: \mathrm{C}$} \\
\cline { 2 - 4 } & $\mathrm{C} 1 \mathrm{~s}$ & $\mathrm{~N} 1 \mathrm{~s}$ & $\mathrm{0} \mathrm{1s}$ & \\
\hline 700 & 80.18 & 7.44 & 11.94 & 0.093 \\
800 & 87.31 & 5.10 & 7.18 & 0.058 \\
900 & 89.65 & 3.33 & 6.50 & 0.037 \\
1000 & 91.80 & 2.12 & 5.88 & 0.023 \\
\hline
\end{tabular}



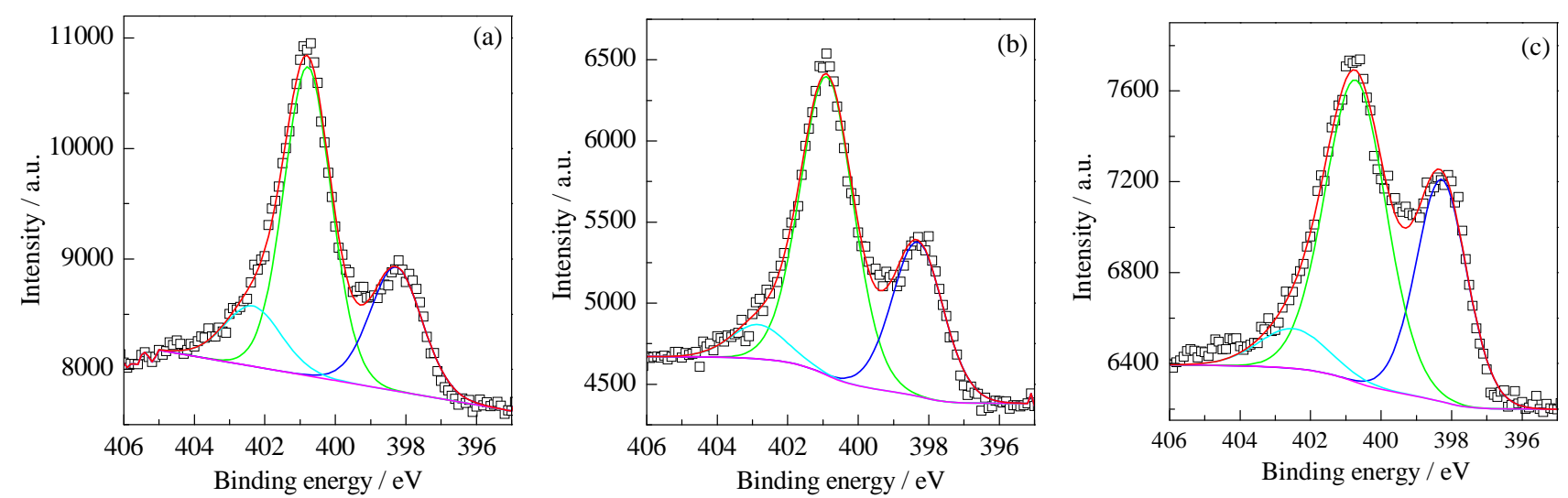

Fig. 4. N $1 s$ peak and peak fitting results for C-PA-900 (a), C-PY-900 (b), and C-Phen-900 (c).

Table 4

Nitrogen component composition (\%) of the synthesized NOMCs.

\begin{tabular}{lccc}
\hline Sample & Pyridinic-N & Graphitic-N & Oxide-N \\
\hline C-PA-900 & 26.42 & 59.55 & 14.03 \\
C-PY-900 & 30.85 & 64.02 & 7.31 \\
C-Phen-900 & 34.74 & 56.86 & 8.42 \\
\hline
\end{tabular}

lar for the three NOMCs, and the graphitic-nitrogen is the dominant component. Quantitative analysis (Table 4) shows that the content of each component differs, indicating that the precursor influences the nitrogen doping. For example, the edge-type nitrogen, viz. pyridinic-nitrogen, increases in the order C-PA-900 < C-PY-900 < C-Phen-900. The edge-type nitrogen is acknowledged to be a highly effective dopant for electrocatalysis [26-29]. Therefore, this result may yield a positive effect on the electrocatalytic activity, as discussed below.

In our previous work, the ORR active sites are claimed to be the nitrogen-activated carbon $[19,20]$. As such, curve fitting of the high-resolution C 1 s peak is performed (Fig. 5 and Table 5). It is observed that the nitrogen-activated carbon composition is $15.60 \%$ for C-PA-900, $19.87 \%$ for C-PY-900, and $23.04 \%$ for C-Phen-900; therefore, it can be expected that the ORR electrocatalytic activity follows the order: C-PA-900 < C-PY-900 < C-Phen-900.

Fig. 6 shows the cyclic voltammograms of the three NOMCs.
Table 5

Carbon component composition (\%) of the synthesized NOMC materials.

\begin{tabular}{lccccc}
\hline Sample & C-C=C & C-C-N & C-O/C=N & C=0 & COOH \\
\hline C-PA-900 & 68.29 & 15.60 & 8.81 & 5.46 & 1.84 \\
C-PY-900 & 66.36 & 19.87 & 5.77 & 5.50 & 2.50 \\
C-Phen-900 & 65.53 & 23.04 & 5.60 & 4.53 & 1.30 \\
\hline
\end{tabular}

The curves are similar in shape, featuring a large capacitive current, which originates from the high specific surface area (vide supra). A broad electrochemically reversible wave is observed in the potential range of $0-0.8 \mathrm{~V}$, which has been attributed to the adsorption-desorption of hydroxyl ions. Specifically, C-Phen-900 shows the highest pseudocapacitive current and a unique redox couple at $0.6 \mathrm{~V}$, indicating the presence of more electrochemically active functional groups on the surface [20].

Fig. 7 shows the ORR polarization curves and the $\mathrm{H}_{2} \mathrm{O}_{2}$ yield of the NOMC catalysts in an $\mathrm{O}_{2}$-saturated $0.10 \mathrm{~mol} / \mathrm{L} \mathrm{KOH}$ solution. First, Fig. 7(a) reveals that the three catalysts yield equal or even enhanced ORR activity compared with the commercial Pt catalyst. C-Phen-900 shows a half wave potential $\left(E_{1 / 2}\right)$ of $0.89 \mathrm{~V}$, which is higher than C-PY-900 (0.87 V), Pt catalyst $(0.84$ V), and C-PA-900 (0.83 V). Fig. 7(b) shows that the electron transfer number is approximately 4 (C-PA-900: 3.3-3.9,
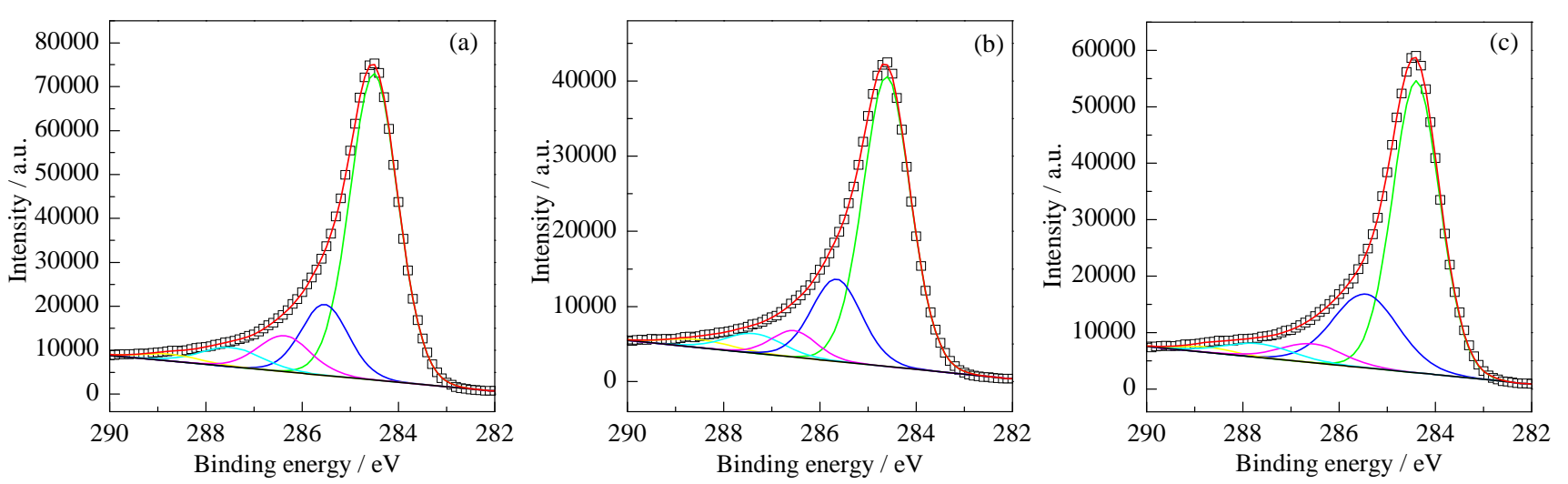

Fig. 5. C $1 s$ peak and peak fitting results for C-PA-900 (a), C-PY-900 (b), and C-Phen-900 (c). 


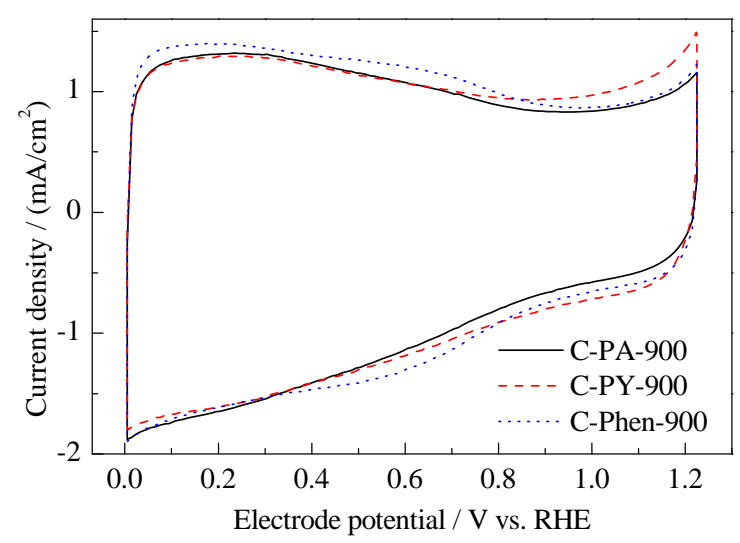

Fig. 6. Cyclic voltammograms of NOMCs in an Ar-saturated $0.10 \mathrm{~mol} / \mathrm{L}$ $\mathrm{KOH}$ solution.

C-PY-900: 3.5-4.0, C-Phen-900: 3.6-4.0), indicating a reaction highly selective to the complete reduction of oxygen. The high electrocatalytic activity of these materials can first be attributed to the uniform mesoporous structure associated with the high specific surface area (vide supra). Second, it is observed that the precursor significantly influences the electrochemical behavior, and the electrocatalytic activity follows the order: C-PA-900 < C-PY-900 < C-Phen-900. This result correlates well to the above-mentioned compositional change of the nitrogen-activated carbon, which confirms our claim on the chemical nature of the active sites. Finally, it is noted that C-Phen-900 shows a higher limited current density. The reason remains unclear; however, this may result from the well-defined ordered mesoporous structure (Fig. 2). In summary, the above findings indicate that both the NOMC itself and the electrochemical properties can be tailored by varying the precursor.

\section{Conclusions}

In this work, the NOMC catalysts are synthesized through a nanocasting method employing three carbon precursors: polyaniline, polypyrrole, and phenanthroline. The synthesized NOMC catalysts yield superior ORR electrocatalytic activity and selectivity. In addition to the hard template, the textural properties of the NOMCs closely relate to the carbon precursor used, which significantly influences both the electrocatalysis and mass transfer. Second, the content of the edge-type nitrogen is dependent on the carbon precursor, and is observed to be highest when using phenanthroline as the precursor. The composition of the nitrogen-activated carbon atoms follows the order: C-PA-900 < C-PY-900 < C-Phen-900, and furthermore, the electrocatalytic activity follows the same order, confirming the claim that the nitrogen-activated carbon atoms are the active sites. This work not only yields superior non-noble metal electrocatalysts for fuel cell applications, but also offers further experimental design to tailor the carbon type during pyrolysis-based protocols.

\section{References}

[1] J. J. Xiao, X. J. Bian, L. Liao, S. Zhang, C. Ji, B. H. Liu, ACS Appl. Mater. Interface, 2014, 6, 17654-17660.

[2] F. Y. Cheng, J. Chen, Chem. Soc. Rev., 2012, 41, 2172-2192.

[3] Y. Qin, J. Lu, P. Du, Z. H. Chen, Y. Ren, T. P. Wu, J. T. Miller, J. G. Wen, D. J. Miller, Z. C. Zhang, K. Amine, Energy Environ. Sci., 2013, 6, 519-531.

[4] S. G. Lee, M. Choun, Y. J. Ye, J. Lee, Y. Mun, E. Kang, J. Hwang, Y. H. Lee, C. H. Shin, S. H. Moon, S. K. Kim, E. Lee, J. Lee, Angew. Chem. Int. Ed., 2015, 54, 9230-9234.

[5] M. Ferrandon, A. J. Kropf, D. J. Myers, K. Artyushkova, U. Kramm, P. Bogdanoff, G. Wu, C. M. Johnston, P. Zelenay, J. Phys. Chem. C, 2012,

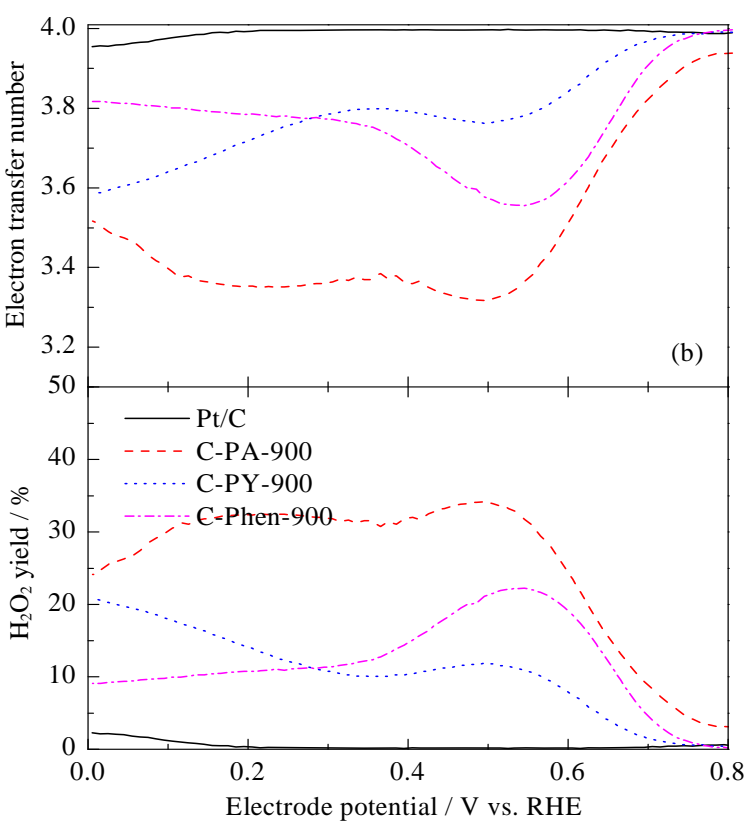

Fig. 7. Rotating ring-disk electrode results of the synthesized NOMC materials in an $\mathrm{O}_{2}$-saturated $0.10 \mathrm{~mol} / \mathrm{L} \mathrm{KOH}$ solution (rotating speed 1600 $\mathrm{r} / \mathrm{min}$ ). (a) Background-corrected oxygen reduction reaction polarization curve and the corresponding ring current; (b) Electron transfer number and $\mathrm{H}_{2} \mathrm{O}_{2}$ yield. 


\title{
Graphical Abstract
}

Chin. J. Catal., 2016, 37: 1562-1568 doi: 10.1016/S1872-2067(16)62498-1

\section{Nitrogen-doped ordered mesoporous carbon: Effect of carbon precursor on oxygen reduction reactions}

Xiao-hua Li, Kai Wan, Quan-bing Liu, Jin-hua Piao, Yu-ying Zheng, Zhen-xing Liang *

South China University of Technology; Guangdong University of Technology

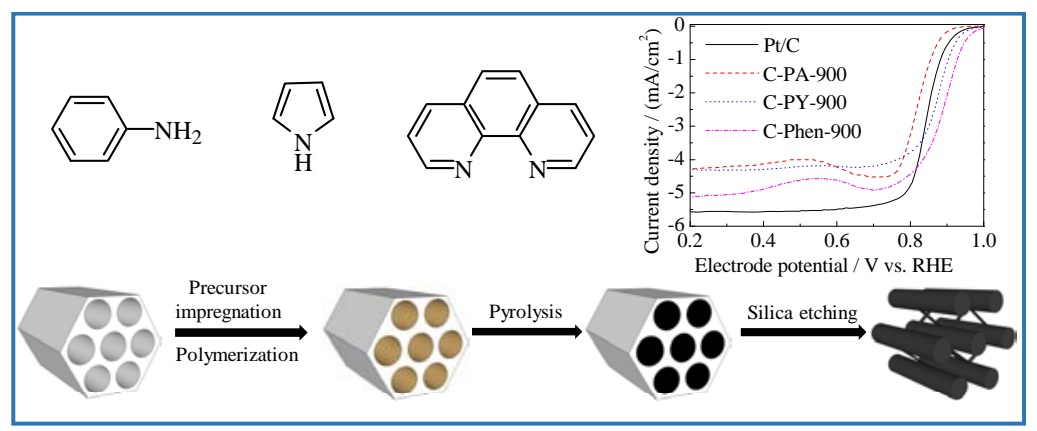

This work investigated carbon precursor influence on resultant nitrogen-doped ordered mesoporous carbon electrocatalysts. Precursors significantly influence both the composition and textural properties. Precursor and experimental pyrolysis design improves electrocatalytic activity for the oxygen reduction reaction.

116, 16001-16013.

[6] D. Qazzazie, M. Beckert, R. Mülhaupt, O. Yurchenko, G. Urban, Electrochim. Acta, 2015, 186, 579-590.

[7] G. Liu, X. G Li, P. Ganesan, B. N. Popov, Electrochim. Acta, 2010, 55, 2853-2858.

[8] M. Lefèvre, J. P. Dodelet, Electrochim. Acta, 2008, 53, 8269-8276.

[9] P. Chen, T. Y. Xiao, Y. H. Qian, S. S. Li, S. H. Yu, Adv. Mater., 2013, 25 , 3192-3196.

[10] W. J. Lu, M. X. Liu, L. Miao, D. Z. Zhu, X. Wang, H. Duan, Z. W. Wang, L. C. Li, Z. J. Xu, L. H. Gan, L. G. Chen, Electrochim. Acta, 2016, 205, 132-141.

[11] Y. H. Zhao, M. X. Liu, X. X. Deng, L. Miao, P. K. Tripathi, X. Ma, D. Z. Zhu, Z. J. Xu, Z. X. Hao, L. H. Gan, Electrochim. Acta, 2015, 153, 448-455.

[12] N. N. Liu, L. G. Yin, C. G. Wang, L. Y. Zhang, N. Lun, D. Xiang, Y. X. Qi, R. Gao, Carbon, 2010, 48, 3579-3591.

[13] R. Gadiou, A. Didion, R. I. Gearba, D. A. Ivanov, I. Czekaj, R. Kötz, C. Vix-Guterl, J. Phys. Chem. Solids, 2008, 69, 1808-1814.

[14] A. Vinu, K. Ariga, T. Mori, T. Nakanishi, S. Hishita, D. Golberg, Y. Bando, Adv. Mater., 2005, 17, 1648-1652.

[15] M. L. Guo, J. H. Chen, J. Li, B. Tao, S. Z. Yao, Anal. Chim. Acta, 2005, 532, 71-77.

[16] M. Bron, J. Radnik, M. Fieber-Erdmann, P. Bogdanoff, S. Fiechter, J. Electroanal. Chem., 2002, 535, 113-119.

[17] Z. X. Liang, H. Y. Song, S. J. Liao J. Phys. Chem. C, 2011, 115,
2604-2610.

[18] G. F. Long, K. Wan, M. Y. Liu, X. H. Li, Z. X. Liang, J. H. Piao, Chin. J. Catal., 2015, 36, 1197-1204.

[19] K. Wan, Z. P. Yu, X. H. Li, M. Y. Liu, G. Yang, J. H. Piao, Z. X. Liang, ACS Catal., 2015, 5, 4325-4332.

[20] K. Wan, G. F. Long, M. Y. Liu, L. Du, Z. X. Liang, P. Tsiakaras, Appl. Catal. B, 2015, 165, 566-571.

[21] K. Wan, Z. P. Yu, Z. X. Liang, Catalysts, 2015, 5, 1034-1045.

[22] N. Iwashita, C. R. Park, H. Fujimoto, M. Shiraishi, M. Inagaki, Carbon, 2004, 42, 701-714.

[23] G. Wu, P. Zelenay, Acc. Chem. Res., 2013, 46, 1878-1889.

[24] S. Chen, J. Y. Bi, Y. Zhao, L. J. Yang, Z. Chen, Y. W. Ma, Q. Wu, X. Z. Wang, Z. Hu, Adv. Mater., 2012, 24, 5593-5597.

[25] Y. Hu, J. O. Jensen, W. Zhang, L. N. Cleemann, W. Xing, N. J. Bjerrum, Q. F. Li, Angew. Chem. Int. Ed., 2014, 53, 3675-3679.

[26] F. Jaouen, E. Proietti, M. Lefevre, R. Chenitz, J. P. Dodelet, G. Wu, H. T. Chung, C. M. Johnston, P. Zelenay, Energy Environ. Sci., 2011, 4, 114-130.

[27] J. Tian, A. Morozan, M. T. Sougrati, M. Lefevre, R. Chenitz, J. P. Dodelet, D. Jones, F. Jaouen, Angew. Chem. Int. Ed., 2013, 52, 6867-6870.

[28] U. I. Kramm, M. Lefevre, N. Larouche, D. Schmeisser, J. P. Dodelet, J. Am. Chem. Soc. 2014, 136, 978-985.

[29] M. H. Shao, Q. W. Chang, J. P. Dodelet, R. Chenitz, Chem. Rev., 2016, 116, 3594-3657.

\section{含氮前驱体对氮杂有序介孔炭材料及其氧还原电催化性能的影响}

\author{
李小花 ${ }^{\mathrm{a}}$, 万 凯 ${ }^{\mathrm{a}}$, 刘全兵 ${ }^{\mathrm{a}}$, 朴金花 ${ }^{\mathrm{b}}$, 郑育英 ${ }^{\mathrm{c}}$, 梁振兴 ${ }^{\mathrm{a},{ }^{*}}$ \\ a华南理工大学化学与化工学院, 广东省燃料电池技术重点实验室, 广东广州510641 \\ b华南理工大学轻工与食品学院, 广东广州510641 \\ c 广东工业大学轻工化工学院, 广东广州510006
}

摘要: 燃料电池中贵金属铂的大量使用是阻碍其发展的关键因素, 亟需探索高效廉价的替代型电催化剂. 在目前的替代型 非贵金属催化剂研究中, 氮杂炭材料是一类氧还原反应催化活性最好、成本最低廉的催化剂, 被认为是最有可能取代 Pt 催 
化剂而获得实际应用的催化剂. 氮杂有序介孔炭材料因具有极高的比表面积和规整的孔道结构, 可实现活性位点的密集 组装与反应物料的快速传输, 受到研究者的广泛关注. 本文分别以苯胺、吡咯和邻菲罗啉为含氮前驱体, 介孔分子篮 SBA-15 为硬模板, 采用纳米浇铸法成功制备了具有高比表面积的氮杂有序介孔炭材料, 系统研究了不同含氮前驱体对氮 杂有序介孔炭材料的影响. 采用氮气吸附-脱附等温线、透射电子显微镜 (TEM)、X射线衍射 (XRD) 和X射线光电子能谱 (XPS) 等方法研究了氮杂有序介孔炭的组成与结构, 采用循环伏安法 (CV) 以及线性扫描伏安法 (LSV) 等手段考察了其电 化学行为与氧还原反应极化性能.

氮气吸附-脱附等温线结果表明, 采用三种不同含氮前驱体制备的氮杂炭材料都对应 IV 型吸脱附等温线以及 H4 型滞 后环, 表明所制备的氮杂炭材料具有介孔结构. 由 TEM 可以清楚地观察到氮杂炭材料已经成功地反转了 SBA-15 模板的 孔道结构. 同时发现, 含氮前驱体对氮杂炭材料的比表面积和孔结构产生较大影响: 以吡咯和邻菲罗啉为前驱体制备的炭 材料 C-PY-900 和 C-Phen-900 的比表面积较高, 分别为 765 和 $746 \mathrm{~m}^{2} / \mathrm{g}$, 而以苯胺为前驱体制备的炭材料 C-PA-900 比表 面积较小 $\left(569 \mathrm{~m}^{2} / \mathrm{g}\right)$; 三种炭材料平均孔径大小顺序为 C-Phen-900 $(3.7 \mathrm{~nm})<$ C-PY-900 $(5.0 \mathrm{~nm})<$ C-PA-900 $(5.9 \mathrm{~nm})$, 这 是由于不同含氮前驱体在高温焙烧过程中热分解行为不同所致. XRD 结果发现, 含氮前驱体对氮杂炭材料的唱型基本没 有影响, 均为无定形碳. XPS 结果表明, 采用苯胺、吡咯以及林菲啰啉为前驱体制备的氮杂炭材料中氮含量基本相同, 分别 为 $3.13 \mathrm{at} \%, 3.32 \mathrm{at} \%$ 和 $3.33 \mathrm{at} \%$, 说明在相同热解条件下材料中的氮含量基本不受前驱体的影响, 但不同配位环境的氮含 量以及氮活化碳原子的含量却有较大差异, 其氮活化碳原子的相对含量分别为 $15.60 \%, 19.87 \%$ 和 $23.04 \%$.

电化学测试结果表明, 三种氮杂介孔炭材料的氧还原反应电催化活性顺序为 C-PA-900 < C-PY-900 < C-Phen-900, 其 $\mathrm{H}_{2} \mathrm{O}_{2}$ 产率低于 $30 \%$, 说明氧还原反应经历 4 电子转移路径. 在碱性条件下, 所制氮杂有序介孔炭材料 C-PY-900 和 C-Phen-900 表现出较商品 Pt/C 催化剂更加优异的氧还原反应电催化性能.

综上可见, 通过改变含氮前驱体的类型可以有效调变氮杂炭材料的比表面积、孔道结构以及 $\mathrm{N} 1 \mathrm{~s}$ 与 C $1 \mathrm{~s}$ 化学态, 从而 调控氧还原反应活性. 本文不仅制备出高活性的非贵金属氧还原电催化剂, 同时也为高活性炭基电催化剂的可控制备提 供了思路.

关键词: 电催化; 燃料电池; 氮杂有序介孔炭; 氧还原反应; 前驱体

收稿日期: 2016-05-31. 接受日期: 2016-06-29. 出版日期: 2016-00-05.

*通讯联系人. 电话: (020)87113584; 电子信箱: zliang@scut.edu.cn

基金来源：国家自然科学基金 (21476087, 21576101); 广东省教育厅特色创新项目 (2014KTSCX016); 广东省科技计划 (2013B010405005, 2014A010105041); 中央高校基本科研业务费.

本文的英文电子版由Elsevier出版社在ScienceDirect上出版(http://www.sciencedirect.com/science/journal/18722067). 